\title{
Ireland's Diaspora Strategies and Economic Development
}

\author{
Zili Tian \\ School of International Studies of Jinan University \\ Guangzhou, China \\ 39225676@qq.com
}

\author{
Jinping Wu \\ School of International Studies of Jinan University \\ Guangzhou, China \\ 1102057497@qq.com
}

\begin{abstract}
Many countries hope to make use of the diaspora resource to develop their home-country's economy and social conditions. Ireland is the country which has successful strategies of diaspora practices. It formulated a series of policies to mobilize nearly 80 million diasporas to contribute to the home country, which finally made the glory era of "Celtic Tiger". This paper is to analyze Irish successful experience to understand the relationship between the Irish diaspora and economy development, which would help us to make our Chinese diaspora strategies well. We believe that the successful of Irish foreign capital inflows, the establishment of pillar industry, the building of professional and technical network, the promotion of tourism industry and the peace process in Northern Ireland were contributed to the Ireland's government's great diaspora strategies, which attracted a large number of diasporas to return to Ireland. Irish diaspora strategies play an important role in Irish foreign-oriented economic construction.
\end{abstract}

Keywords-disapora strategies; home country; economy; development

\section{INTRODUCTION}

Today, as an important resource of many countries, diaspora gets more and more attention. Many countries hope to make use of the capital, technology, experience, and social network of diaspora to develop their own economy. As a smallpellet country, Ireland is far away from Europe Continent, which is considered as one of the poorest countries in the Europe Union during a long period. In 1980s, with the weak and poverty situation of Ireland, the government formulated a series of policies to mobilize nearly 80 million diasporas and made use of their resources to promote the national economy and social development, which finally made the glory era of "Celtic Tiger". The economy of the traditional agriculture country with only 70 thousands square kilometers and 463.54 million populations developed rapidly at the end of the 20th century. As a typical case, Ireland has made full use of diasporas to achieve its own great development. The successful way of Ireland must have its own knack. So, this paper is to analyze the successful way of Ireland by means of initial inquiry of the Irish rich and successful Diaspora practices.

In 1980s, in order to develop the domestic economy, the Irish government mobilized the diaspora to participate in the construction of the home country actively, which finally contributed to the glorious history of "Celtic Tiger". This paper attempts to describe the interaction between the Irish diaspora and the home country's economy, then, to clarify the motivation of Irish diaspora to participate in the economic construction of home country, and to find out the impact of them to the home country's economic development.

\section{DIASPORA STRATEGIES: DEVELOPMENT OF IRELAND'S ECONOMY}

\section{A. Diaspora Strategies}

"Diaspora" is a Greek word which originally means "to sow over or scatter.” Until fairly recently, the historical Jewish experience provided the archetype: forced expulsion and dispersal, persecution, a sense of loss, and a vision of return. Over the past decade or so, however, "Diaspora” has become a term of self-identification among many varied groups who migrated or whose forbearers migrated from one place to another or several other places. [1]

The Political interests and activities of migrant have a long history. More than 100 years ago, the history studies of migrant communities' indicated the considerable degree of political engagement- from afar evident.[1] In Mark Boyle, Rob Kitchin and Delphine Ancien's opinion of the Diaspora Strategy, it is an explicit and systematic policy initiative or series of policy initiatives aimed at developing and managing relationships between homelands and diasporic populations. These policy initiatives vary from highly formalized and structured programmes to projects that are quite light in conception and application.”[3]

All of the scholars in academic circles thought the Ireland diaspora strategies did a good job on the content and adhibition. Irish experience is a good model for all of the other countries. With respect to its content, some scholars thought that the relationship between the diaspora and Ireland is established by contacting and cultivating. The scholars thought there are mainly 5 aspects of the Irish diaspora strategies: (1) providing fund to diaspora; (2) extension the channels between government and diaspora; (3) supporting the development of all types of diaspora organizations; (4) agreeing with the contribution of diaspora; (5) according to the other forms which are needed, such as: cultivate affinity expatriates, etc. Qiuhong Li also had the same opinion. She thought the Irish governments and diaspora maintained friendly relations, which formulated many projects and policies to serve for Irish diaspora. These policies and measures focused on providing administrative services, expanding business contact, promoting 
the exchange of information, expanding charitable welfare, consolidating the diaspora's patriotism, cultivating affinity diaspora, etc. These articles of Irish diaspora strategies made outstanding contributions to the concrete content of Irish diaspora strategies. However, this view was not conducive to grasp the content and the Irish diaspora strategy as a whole. It was not good for us to understand the content of Irish diaspora strategies and the experience of Irish success.

The other scholars thought that the content of the Irish diaspora strategies changed with the Irish economic development. They thought before 2008, the methods of Irish diaspora strategies were to make use of the diaspora resources. After 2008, the government tried to establish a balance strategy model to cultivate diaspora organizations' development. Such kind of view was applied to analyze the development of the Irish diaspora strategies from the aspect of economic crisis in 2008.It talked about the changes of the diaspora strategies, without referring to the reasons of the changed Irish diaspora strategies.

From all of these, it comes no doubt that we should analyze the Irish diaspora strategies from the aspect of Irish economic development to understand the logic associations between them, and we also should analyze the content of diaspora strategies totally to promote our country's diaspora strategies.

\section{B. Engaged with Diaspora Generally, there are 5 steps to engage the diaspora:}

Firstly, defining and identifying the Irish Diasporas. The Irish constitute says, the diaspora comprises emigrants from Ireland and their descendants around the world and those with a tangible connection to Ireland. [4]

Secondary, identifying the key development priorities and concreting projects to build a common agenda with Irish Diasporas. Before 2008, the development goal of the Ireland was to tackle the industrial transformation, to set up the pillar industry and get rid of the dependence on the British market. In this period, Ireland set up the Industrial Development Authority to attract foreign investment. In order to attract the diaspora to return and support the Industry development, Ireland also decreased its taxes. At 12.5 percent, Ireland had one of the lowest corporate tax rates in the world. [5] In order to attract the talent of IT industry in America to return, Irish government developed the computer education from the 1980s and cultivated the computer talent to support the transnational corporation to Ireland. After 2008, the major goal of the Irish development was economic recovery. Ireland government changed their ideas from attracting capital to talent to transfer the original industrial layout.

Thirdly, gathering existing data on Irish diaspora in order to make proper policies to utilize the diaspora resource. The process of building -up the IT industry of Ireland is a common example of it to create the pillar industry. The government collected the information of American-Irish, and then, made the decision to build up the IT industry as its pillar industry.

Fourthly, identifying the real needs of the diaspora, and then, attract them to participate in the development programs.
Finally, identify the major problems of diaspora to contribute to the home country.

\section{Utilized the Diaspora}

Before the economic crisis of 2008, the main goals of Ireland were economic development and industry transformation from the Agriculture to Industrialization. Based on such development goals, the government formulated the policies to recognize the Irish diaspora and Irish descendants belonging to the Irish people, simplified the administrative produces, and reduced the tax rate of investment, which finally attracted a large number of overseas funds and companies to promote the development of economy in Ireland.

In my opinion, there are about 5 aspects of the diaspora contributing to the Ireland. They are the foreign capital, pillar industry, diaspora knowledge networks, and tourism industry and peace process of North Ireland. Remittance is a common way for diaspora to contribute to the homeland. Furthermore, Ireland also set up the Irish Industrial Development Authority (IDA) to absorb the foreign direct capital to promote the development of Irish industry.

In Ireland, remittances have a long history. In the 19th to 20th century of Europe, Spain, Italy and Ireland had an era which extremely depended on the remittances. In Ireland, the flow of remittances has more than 3 billion pounds from England. [6] Human capital means the education exchanges, cooperation researches, and immigration forms to contribute to the home country. Cultural capital is to build and promote their country's unique humanities, history, and sports, including of the tourism industry to increase the national soft power, to attract diaspora and affinity diaspora to contribute the homeland's construction. In the aspect of philanthropy, Irish foundation collected more than 3 €billion, the Atlantic Fund collected 5 €billion, the international Ireland fund collected 8.5 €billion to support the development of the Irish. In addition, the Irish Foundation also played an important part in the peace of Northern Ireland process.

Culture is one of the most important reasons why the diaspora choose Ireland as a destination for tourism. Culture is also another reason for the other people all over the world to work and live here. Ireland could make use of diaspora to show the shared values, ideas and hopes of it through the expressions of arts, music, religion and food to attract the foreigner to be the potential affinity diaspora. For example, St. Patrick's Day, as a public, 'carnivalesque' celebration of all Irish, is by and large a creation of the diaspora, and in particular the Irish in America. The effort to promote a St. Patrick's Day would bring $€ 58.3 \mathrm{~m}$ to Irish economy. [7]So, from the aspects of culture and commercial, the festival is very successful.

Diaspora knowledge networks could gather the people of related industry to support the Irish industry development. For example, the Irish Technology Leadership Group (ITLG) is a group of Irish and Irish American senior executives based mainly in Silicon Valley, which is a networking organization. Irish government made use of such organization to support the growth and development of small and start - up Irish technology to seek both the US marketplace and US technology investment community. 
The peace of the North Ireland is a vital factor impacting the development of Ireland. Recently, much of the analysis showed that diaspora played a remarkably important role in peace initiatives of North Ireland Peace Process. Some important diasporas and diaspora groups had the constructive roles in homeland confliction, Such as Bill Clinton, the expresident of America. They contributed to this by facilitating depoliticized discussions and acting as mediator of sorts.

Ireland made use of the common recognition of diaspora, such as culture, norms, values, in order to connect the diaspora into a strong cultural community to effectively mobilize them to participate in home-country's construction. Furthermore, Ireland also utilized the economic power and political influence of diaspora in the host country to affect the policymaking to the home-country. In the event of the North Ireland Peace Procedure, Ireland utilized Irish American group and Irish American Leader to lobby America to involve into the peace process of North Ireland, and then, to make the best policy to promote the development of itself.

\section{Existing PRoblems OF DEVELOPMENT AND POSSIBILITIES FOR ALTERNATIVES}

Ireland suffered the economic collapse for the reason of depending on the foreign investment too much. The Irish government consulted the domestic economy and then located the Irish development goals in "economic recovery" and "knowledge economy". The Irish diaspora strategies adjusted from "funds" to "talents", promoted Irish diaspora organizations development, and maximized the communication between the organizations and diaspora, provided the funds and welfare to Irish abroad, set up Ireland brand to attract diaspora, and nurtured the affinity people of Ireland.

So, in order to develop and enhance the relationships of its diaspora, there are 8 steps to promote the initial diaspora strategies:1) rolling out new administrative structures to support diaspora strategy making; 2) infrastructure connecting between diaspora and the homeland; 3) widening citizenship to the diaspora in certain key ways, not least in the provision of welfare services; 4) building diasporic patriotism through supporting culture activities, education and language learning; 5) promoting philanthropy; 6) building business networks; 7) nurturing return migration; 8) promoting the idea of affinity diaspora.

\section{CONCLUSION}

Compared with other European countries, Irish industrial grand success experience is seen as a foreign direct investment under the achievements of the classic model. Starting in the 70 s, Ireland has adopted a series of feasible strategies for diaspora. They encouraged the diasporas to bring their capital into home country to support the economic development. The diaspora tried to meet the needs of the home country as well as to achieve their economic purpose, set up the software features, biological engineering, finance and other pillar industries of the Irish economy new form. They also contributed to the Irish economic transformation from agriculture and animal husbandry economy to knowledge economy, as well as to improve the position of Ireland in the global economy. During the period of 1994-1998, Ireland's economy developed well and created a splendid history of "Celtic tiger". Ireland's economic development not only needs to expand the domestic market, attract more investment, but also needs to develop the international market, seek foreign market. For all these multiple needs provided the opportunity to the development of communication circle between diaspora and home country. The Irish people all over the world through a variety of different network to exchange information and business opportunities, and other experience and technology .So, diaspora also provided the resources to satisfy the Irish economy development demands, such as capital, technology, etc. After the economic crisis, a large number of professional skills and experience are young Ireland lost overseas; the Irish government realized that encouraging and mobilizing the professional skills, experience and related resources of Ireland that had returned overseas employment is to accelerate the Irish response to the economic crisis, the key to economic recovery. And it should create more jobs and favorable policy environment to attract this part of Irish home work

Irish government made use of the diaspora to develop its economy, set up IT as the pillar industry and transfer the Irish economy structure from farming and animal husbandry to knowledge-based economy. After then, Ireland acquired a reputation as the "Celtic Tiger". The Irish diaspora strategies successfully attracted the Irish abroad to contribute to the home-country and attracted the affinity diaspora to work and live in Ireland too. From all of these, it seems no doubt that the Irish diaspora strategies play an important role in its development .It is a precious experience for other countries as well.

\section{ACKNOWLEDGMENT}

This research was financially supported by the National Social Science Foundation of China (Grant NO. 12BMZ068) .

\section{REFERENCES}

[1] Steven. Vertovec, “The Political Importance of Diasporas,”Migration Policy Institute: http://www.migrationpolicy.org/print/4684,2016-06-21.

[2] Mark Boyle,Rob Kitchin and Delphine Ancien, “The Nirsa Diaspora Strategy Wheel \&Ten Principles of Good Practice,” National University of Ireland, Maynooth:

http://eprints.maynoothuniversity.ie/2055/1/RK_NIRSA_Diaspora_Strat egy_Wheel, 2016-06023.

[3] Department of Foreign Affairs and Trade,"Global Irish: Ireland's Diaspora Policy,” 2015, pp.16.

[4] Barry Mcsweeney, "ICT Supporting the Smart Economy: The Case of Ireland,’The Global Information Technology Report. 2010 World Economic Forum, 2010, pp.141.

[5] Kingsley Aikins, Anita Sands and Nicola White, "The Global Irish Making Difference Together,’Impress Printing Worls, 2009,pp.132.

[6] Marc Scully, "Whose day is it anyway? St. Patrick's Day as a Contested Performance of National and Diasporic Irishness,” Studies in Ethnicity and Nationalism, Vol. 12,2012, pp. 118. 